\title{
Brazing of Zirconia with AgCuTi and SnAgTi Active Filler Metals
}

\author{
T.H. CHUANG, M.S. YEH, and Y.H. CHAI
}

\begin{abstract}
The self-brazing of partially stabilized zirconia using Ag27Cu3Ti and Sn10Ag4Ti active filler metals is investigated. It was shown that the contact angles of $\mathrm{Ag} 27 \mathrm{Cu} 3 \mathrm{Ti}$ and $\mathrm{Sn} 10 \mathrm{Ag} 4 \mathrm{Ti}$ on zirconia decreased with the increase of brazing temperature and remained constant at about 34 deg and 44 deg above $900{ }^{\circ} \mathrm{C}$, respectively. The flexural strengths were 227 and $137 \mathrm{MPa}$ for $\mathrm{ZrO}_{2} / \mathrm{Ag} 27 \mathrm{Cu} 3 \mathrm{Ti} /$ $\mathrm{ZrO}_{2}$ and $\mathrm{ZrO}_{2} / \mathrm{Sn} 10 \mathrm{Ag} 4 \mathrm{Ti} / \mathrm{ZrO}_{2}$, respectively, after brazing at $900{ }^{\circ} \mathrm{C}$ for 10 minutes.

In these brazing systems, the titanium in the filler metals segregated at the interface and formed a $\mathrm{TiO}$ reaction layer responsible for the wetting and bonding when a $\mathrm{ZrO}_{2}$ ceramic is brazed with $\mathrm{Ag} 27 \mathrm{Cu} 3 \mathrm{Ti}$ and $\mathrm{Sn} 10 \mathrm{Ag} 4 \mathrm{Ti}$ filler metals. Interfacial analyses by electron probe microanalysis (EPMA) showed that such $\mathrm{TiO}$ reaction layers of $\mathrm{ZrO}_{2} / \mathrm{Ag} 27 \mathrm{Cu} 3 \mathrm{Ti}$ and $\mathrm{ZrO}_{2} / \mathrm{Sn} 10 \mathrm{Ag} 4 \mathrm{Ti}$ possessed similar thicknesses at the same brazing condition, implying that the TiO interfacial reaction layers of both brazing systems were of the same nature and formation kinetics.
\end{abstract}

\section{INTRODUCTION}

BECAUSE of their special properties such as the ability to bear high temperatures, wear, and corrosion, fine ceramics have a significant potential for many structural and electrical applications. However, in many cases, the different ceramic parts must be connected by ceramic/ceramic joining technologies in order to fabricate complicated shapes or larger sizes. Additionally, other properties of ceramics (such as conductivity and toughness) are not comparable to those of metals. In such cases, ceramics may be joined to metals to obtain useful and stable components. As a result, the ceramic/ ceramic and ceramic/metal joining technologies will be critical for the structural application of fine ceramics in the future. In general, ceramic/ceramic and ceramic/metal joining have, so far, been accomplished by using a metal interlayer either by brazing or diffusion bonding.

Brazing is a convenient way to get a good joint. However, in either ceramic/ceramic or ceramic/metal joining, the poor wettability of conventional filler metals on ceramics is the critical problem in using the brazing method. ${ }^{[1,2]}$ To improve wettability, active elements such as titanium, zirconium, or hafnium are added to conventional filler metals, due to the chemical affinity of the active elements with the oxygen in oxide ceramics $^{[3]}$ or the carbon and nitrogen in carbide ${ }^{[4,5]}$ and nitride ceramics, ${ }^{[6,7]}$ respectively.

In general, the active fillers can be divided into three groups, according to their melting points.

(1) Low-melting-point active fillers: $:^{[8]}$ those with a melting point below $400{ }^{\circ} \mathrm{C}$, a typical example being the addition of titanium to lead- or tin-based solders.

(2) Medium-melting-point active fillers: ${ }^{[3]}$ those with a melting point between $700{ }^{\circ} \mathrm{C}$ and $1000{ }^{\circ} \mathrm{C}$, a typical

T.H. CHUANG, Professor, is with the Institute of Materials Science and Engineering, National Taiwan University, Taipei, 106 Taiwan, Republic of China. M.S. YEH, Associate Professor, is with the Department of Mechanical Engineering, Chung-Hua University, Hsin-Chu, 300 Taiwan, Republic of China. Y.H. CHAI, Design Engineering, is with the Micro Design and Development Division, NEC Electronics, Inc., Santa Clara, CA 950528062.

Manuscript submitted November 10, 1998. example being the addition of titanium to silver- or silver-copper-based fillers.

(3) High-melting-point active fillers: ${ }^{[9,10]}$ those with a melting point above $1000{ }^{\circ} \mathrm{C}$, a typical example being the addition of titanium to platinum-, palladium-, or goldbased noble-metal fillers.

Among them, the most common active filler is the eutectic $72 \mathrm{Ag}-28 \mathrm{Cu}$ with an addition of about $3 \mathrm{wt}$ pet titanium. It has been shown that good joints can be obtained with many oxide and nonoxide ceramics by using these kinds of active fillers ${ }^{[3-6]}$ However, the interfacial thermal stress generated due to the difference in thermal-expansion coefficients of the ceramic and metal during the cooling process after brazing might deteriorate the joints. To solve this problem, lowmelting-point active fillers have been developed. Although the brazing was also conducted at higher temperatures, the active fillers solidified at lower temperatures, which effectively alleviated the thermal stress between ceramic and metal.

Okamoto indicated in a review article that interfacial reactions are unavoidable in most metal-ceramic joining. ${ }^{[11]}$ The formation of interfacial phases affects the wetting process and the joining strength of the brazed ceramic components. However, Chung and Iseki demonstrated that the joining of ceramics could be accomplished by adsorption of the $\mathrm{Ti}$ element on the interface, regardless of whether an interfacial reaction layer was formed. ${ }^{[12]}$ For the brazing of $\mathrm{Al}_{2} \mathrm{O}_{3}, \mathrm{SiC}$, and $\mathrm{Si}_{3} \mathrm{~N}_{4}$ with $\mathrm{AgCuTi}$ active fillers, many research efforts have shown that the Ti in active fillers can react with $\mathrm{Al}_{2} \mathrm{O}_{3}$, $\mathrm{SiC}$, and $\mathrm{Si}_{3} \mathrm{~N}_{4}$ to form titanium oxides, ${ }^{[13,14,15]}$ titanium silicides, ${ }^{[5]}$ titanium carbides, ${ }^{[5,16]}$ and titanium nitrides, ${ }^{[6]}$ respectively. However, the brazing mechanism and the possibly related interfacial reactions between $\mathrm{ZrO}_{2}$ and active fillers have been less often reported.

In our study, in addition to the popular eutectic $\mathrm{Ag} 27 \mathrm{Cu} 3 \mathrm{Ti}$ active filler used to braze the zirconia/zirconia joint, the newly developed low-melting-point active filler $\mathrm{Sn} 10 \mathrm{Ag} 4 \mathrm{Ti}$ was also used to compare the results. Additionally, the interfacial reaction temperature (when a phase transformation takes place within the mix) of the active fillers with 


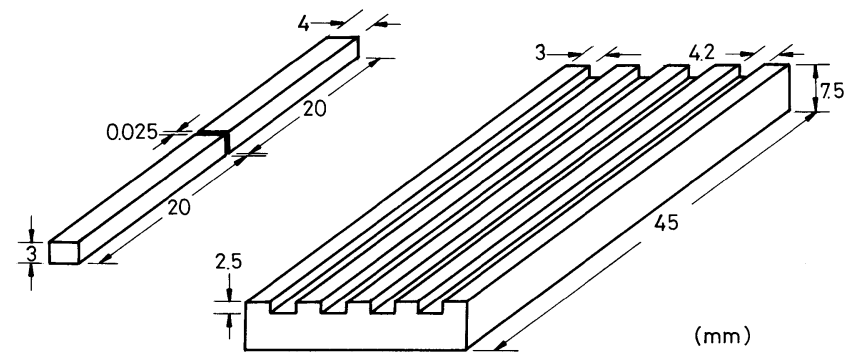

Fig. 1-Ceramic/filler metal/ceramic specimens and assembly brazing holder.

Table I. The Chemical Compositions, Liquidus and Solidus Temperatures, and Strength of the Active Filler Metals

\begin{tabular}{ccccc}
\hline $\begin{array}{c}\text { Filler } \\
\text { Metals }\end{array}$ & $\begin{array}{c}\text { Compositions } \\
\text { (Wt Pct) }\end{array}$ & $\begin{array}{c}\text { Liquidus } \\
\text { Tempera- } \\
\text { ture }\left({ }^{\circ} \mathrm{C}\right)\end{array}$ & $\begin{array}{c}\text { Solidus } \\
\text { Tempera- } \\
\text { ture }\left({ }^{\circ} \mathrm{C}\right)\end{array}$ & $\begin{array}{c}\text { Strength } \\
(\mathrm{MPa})\end{array}$ \\
\hline $\mathrm{Ag} 27 \mathrm{Cu} 3 \mathrm{Ti}$ & $70.5 \mathrm{Ag}-26.5 \mathrm{Cu}-3 \mathrm{Ti}$ & 780 & 805 & 68 \\
$\mathrm{Sn} 10 \mathrm{Ag} 4 \mathrm{Ti}$ & $10 \mathrm{Ag}-86 \mathrm{Sn}-4 \mathrm{Ti}$ & 221 & 300 & 57 \\
\hline
\end{tabular}

zirconia ceramic was evaluated by differential thermal analysis (DTA), revealing comparable data to that of the critical wetting temperature measured by the contact-angle experiments. Furthermore, the interfacial bonding strengths of the zirconia/AgCuTi/zirconia and the zirconia/SnAgTi/zirconia joints were measured by a four-point bending test, and the brazing mechanism and the related possible interfacial reactions were discussed.

\section{EXPERIMENTAL PROCEDURE}

The interfacial reaction temperatures of active fillers and ceramics were evaluated by DTA. A DUPONT* 2000 ana-

*DUPONT is a trademark of E.I. DuPont de Nemours, Wilmington, DE.

lyzer was used. In the DTA curve, the upward peak indicates an exothermic reaction and the downward peak indicates an endothermic reaction. To obtain a much-more-obvious peak, $25 \mathrm{mg}$ ceramic powder was mixed with the active fillers to increase the reaction surface areas. The heating rate was 10 ${ }^{\circ} \mathrm{C} / \mathrm{min}$ from room temperature to $1000{ }^{\circ} \mathrm{C}$, in an argon atmosphere.

The zirconia ceramic Y-PSZ contains 5.02 wt pct $\mathrm{Y}_{2} \mathrm{O}_{3}$ and has a mean particle size of $0.026 \mu \mathrm{m}$ (supplied by TOSOH Co. (US Div., N.J., USA), Japan). The powder was initially dry pressed at $10 \mathrm{~kg} / \mathrm{cm}^{2}$ to a green compact of 5 $\times 5.7 \times 50 \mathrm{~mm}$ and then sintered at $1500{ }^{\circ} \mathrm{C}$ for 1.5 hours. The test bars for bonding were cut from the bulk plate to dimensions of $3 \times 4 \times 20 \mathrm{~mm}$, and the bonding surfaces were ground and polished through diamond paste to an arithmetical average roughness $(\mathrm{Ra})$ of $0.3 \mu \mathrm{m}$. The test bars were then placed into a fixture, as shown in Figure 1, and the active filler was inserted in between. Both filler metals of $\mathrm{Ag} 27 \mathrm{Cu} 3 \mathrm{Ti}$ and $\mathrm{Sn} 10 \mathrm{Ag} 4 \mathrm{Ti}$ were in the form of a foil with a $0.025-\mathrm{mm}$ thickness (supplied by the Degussa Co., Hanau, Germany). The chemical compositions and melting ranges (liquidus and solidus) of both active fillers are also provided by the Degussa Co. (Table I). The brazing
Table II. Bonding Strengths of the Specimens Brazed with the Active Filler Metals in this Study

\begin{tabular}{cccc}
\hline Group & Filler Metals & Brazing Condition & $\begin{array}{c}\text { Bonding Strength } \\
(\mathrm{MPa})\end{array}$ \\
\hline A & $\mathrm{Ag} 27 \mathrm{Cu} 3 \mathrm{Ti}$ & $900^{\circ} \mathrm{C}, 10 \mathrm{~min}$ & 227 \\
B & $\mathrm{Sn} 10 \mathrm{Ag} 4 \mathrm{Ti}$ & $900^{\circ} \mathrm{C}, 10 \mathrm{~min}$ & 137 \\
\hline
\end{tabular}

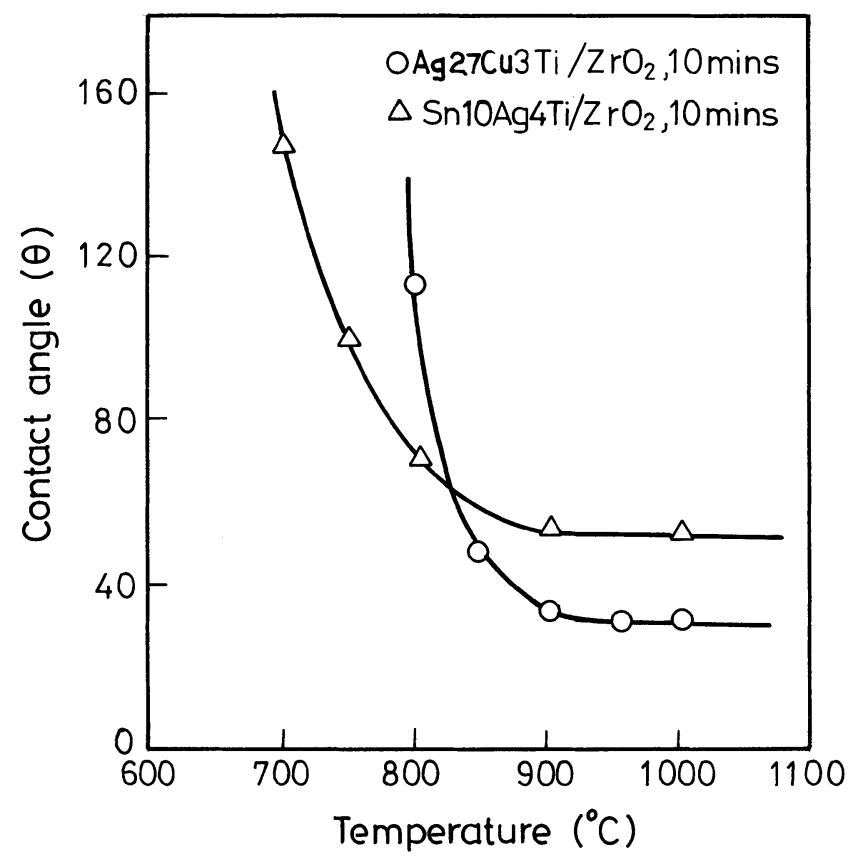

Fig. 2-The contact angle of $\mathrm{Ag} 27 \mathrm{Cu} 3 \mathrm{Ti}$ and Sn10Ag4Ti filler metals on $\mathrm{ZrO}_{2}$ substrate as a function of temperature.

was conducted in a resistance furnace with a vacuum of approximately $10^{-4}$ torr, where the brazing temperature was $900{ }^{\circ} \mathrm{C}$ and the duration was 10 minutes. After brazing, the bonding strength of the joint was measured by the fourpoint bending test. The upper span is $30 \mathrm{~mm}$, the lower span is $10 \mathrm{~mm}$, and the crosshead speed is $0.1 \mathrm{~mm} / \mathrm{min}$. Five specimens were used for each brazing condition, and the average bonding strength is reported (Table II). In order to examine the bonding mechanism and the related interfacial reactions, polished cross sections of ceramic/filler/ceramic joints were examined using electron probe microanalysis (EPMA). The distributions of elements across the ceramic/ filler metal interfaces were also analyzed by EPMA elemental mapping, particularly the distribution of active-element titanium. In addition, the wettability between the active fillers and the zicronia ceramics was evaluated by contactangle $(\theta)$ measurements, using the sessile drop test at various temperatures for 10 minutes, which corresponded to the brazing duration in this study.

\section{RESULTS AND DISCUSSION}

The wetting behavior of $\mathrm{Ag} 27 \mathrm{Cu} 3 \mathrm{Ti}$ and $\mathrm{Sn} 10 \mathrm{Ag} 4 \mathrm{Ti}$ filler metals on zirconia substrates is shown in Figure 2. For both filler metals, the contact angles decreased with increasing temperature. The $\mathrm{Ag} 27 \mathrm{Cu} 3 \mathrm{Ti}$ filler metal could not wet the 


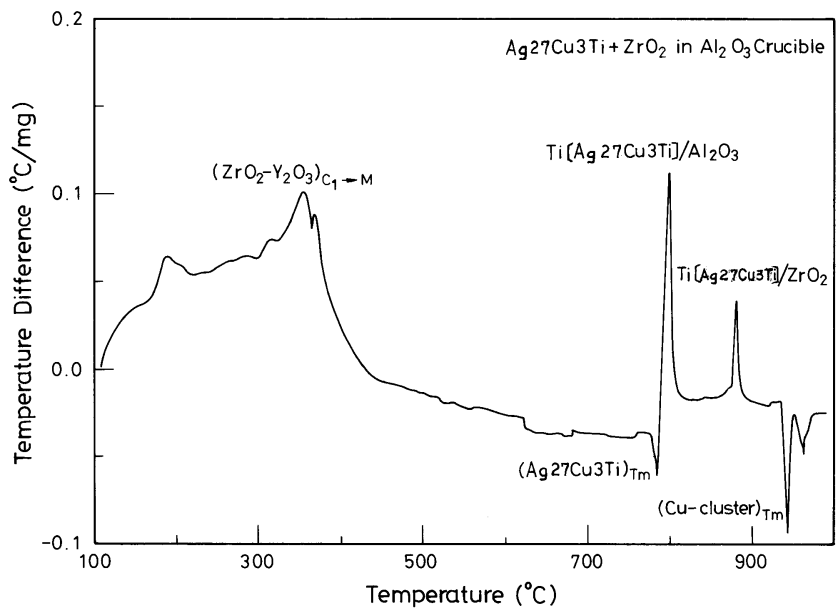

(a)

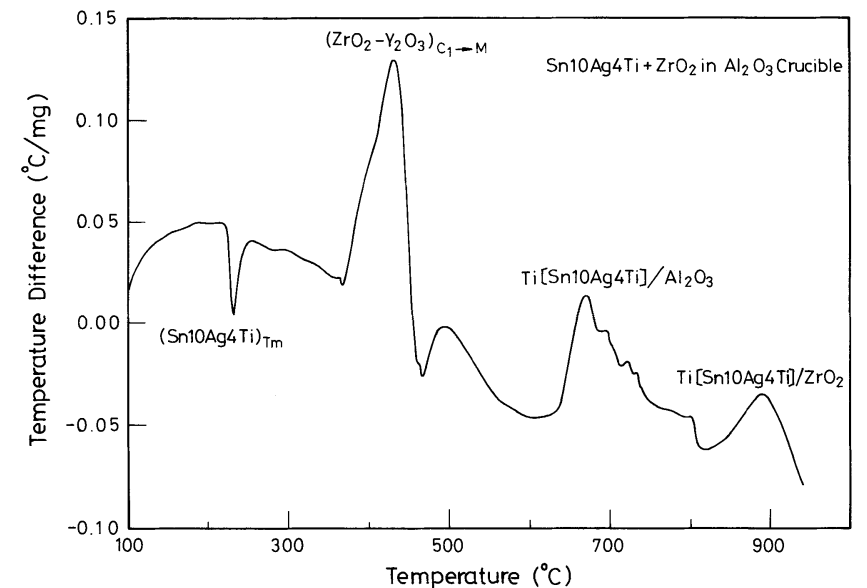

(b)

Fig. 3-DTA analyses for (a) $\mathrm{Ag} 27 \mathrm{Cu} 3 \mathrm{Ti} / \mathrm{ZrO}_{2}$ and $(b) \mathrm{Sn} 10 \mathrm{Ag} 4 \mathrm{Ti} / \mathrm{ZrO}_{2}$ systems.

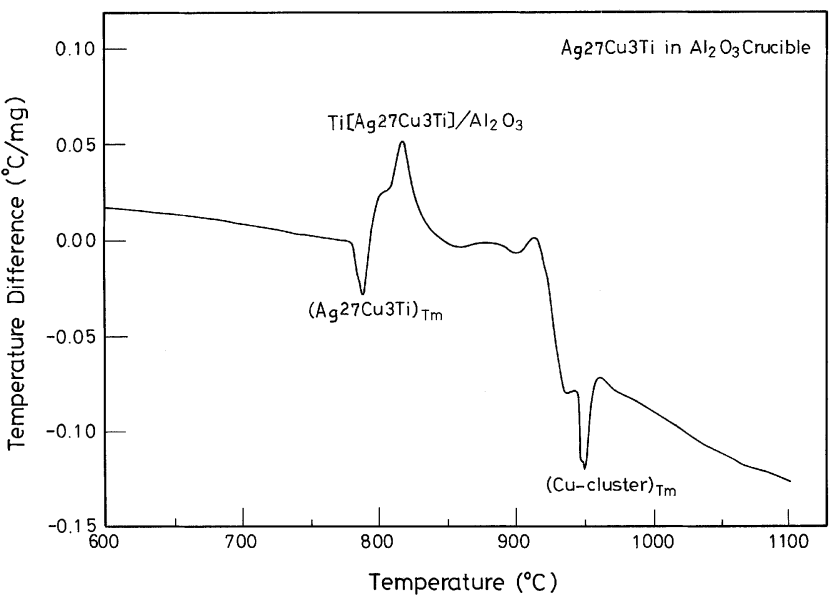

(a)

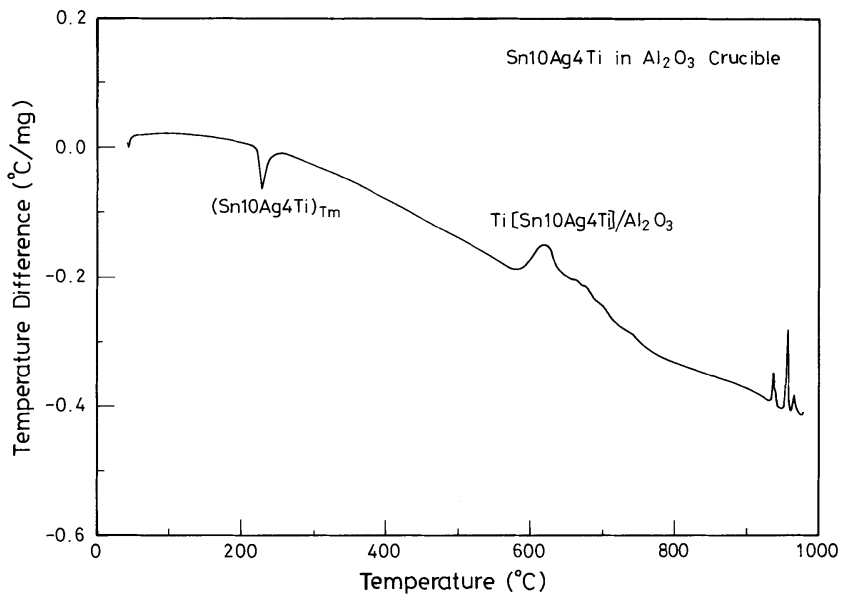

(b)

Fig. 4-DTA analyses for (a) Ag27Cu3Ti and (b) Sn10Ag4Ti with $\mathrm{Al}_{2} \mathrm{O}_{3}$ crucible.

zirconia substrate until the temperature reached approximately $800{ }^{\circ} \mathrm{C}$. However, the contact angle of the $\mathrm{Ag} 27 \mathrm{Cu} 3 \mathrm{Ti} / \mathrm{ZrO}_{2}$ system decreased drastically to about 34 deg after 10 minutes at $900{ }^{\circ} \mathrm{C}$ and remained constant at higher temperatures. In the other case, the Sn10Ag4Ti filler metal began to wet the zirconia substrate after 10 minutes at approximately $770{ }^{\circ} \mathrm{C}$. The contact angle remained constant at about $44 \mathrm{deg}$ for temperatures higher than $800{ }^{\circ} \mathrm{C}$. This result shows that, although the melting range of the Sn10Ag4Ti filler metal was between $221{ }^{\circ} \mathrm{C}$ and $300{ }^{\circ} \mathrm{C}$, much-higher temperatures are required to wet the zirconia substrate. This result is consistent with the report of Lugscheider and Tillmann that brazing with low-melting filler metals is always conducted at elevated temperatures, owing to a decent thermodynamic activation. ${ }^{[17]}$

The DTAs used to interpret the interfacial reactions of $\mathrm{Ag} 27 \mathrm{Cu} 3 \mathrm{Ti} / \mathrm{ZrO}_{2}$ and $\mathrm{Sn} 10 \mathrm{Ag} 4 \mathrm{Ti} / \mathrm{ZrO}_{2}$ are shown in Figures 3(a) and (b), respectively. Since the crucibles used for DTA were made of $\mathrm{Al}_{2} \mathrm{O}_{3}$, the interfacial reactions of both filler metals with the $\mathrm{Al}_{2} \mathrm{O}_{3}$ crucible should also be considered. For this purpose, $\mathrm{Ag} 27 \mathrm{Cu} 3 \mathrm{Ti}$ and $\mathrm{Sn} 10 \mathrm{Ag} 4 \mathrm{Ti}$ were directly placed into the $\mathrm{Al}_{2} \mathrm{O}_{3}$ crucibles and the DTAs conducted, which are shown in Figures 4(a) and (b), respectively. An endothermic peak appeared between $780{ }^{\circ} \mathrm{C}$ and $805{ }^{\circ} \mathrm{C}$ (Figure 4(a)), corresponding to the melting range of the Ag27Cu3Ti filler metal. Since many $\mathrm{Cu}$-rich clusters were included in the eutectic $\mathrm{Ag} 27 \mathrm{Cu} 3 \mathrm{Ti}$ filler metal, another endothermic peak at $940{ }^{\circ} \mathrm{C}$ to $960{ }^{\circ} \mathrm{C}$ should represent the complete dissolution of these $\mathrm{Cu}$-rich clusters. The exothermic peak at about $800{ }^{\circ} \mathrm{C}$ in Figure 4(a) could, thus, be attributed to the interfacial reaction between $\mathrm{Ti}(\mathrm{Ag} 27 \mathrm{Cu} 3 \mathrm{Ti})$ and the $\mathrm{Al}_{2} \mathrm{O}_{3}$ crucible. Similarly, for the case of Sn10Ag4Ti in Figure $4(\mathrm{~b})$, the endothermic peak at $220{ }^{\circ} \mathrm{C}$ to $250{ }^{\circ} \mathrm{C}$ and the exothermic peak at about $578{ }^{\circ} \mathrm{C}$ to $658{ }^{\circ} \mathrm{C}$ corresponded to the melting range $\left(221^{\circ} \mathrm{C}\right.$ to $\left.300{ }^{\circ} \mathrm{C}\right)$ and interfacial reaction temperature of the $\mathrm{Ti}(\mathrm{Sn} 10 \mathrm{Ag} 4 \mathrm{Ti}) / \mathrm{Al}_{2} \mathrm{O}_{3}$ crucible, respectively. In order to clarify the DTA results for such interfacial reactions of titanium in $\mathrm{Ag} 27 \mathrm{Cu} 3 \mathrm{Ti}$ and Snl0Ag4Ti active filler metals with an $\mathrm{Al}_{2} \mathrm{O}_{3}$ crucible, the titanium powder contained in the $\mathrm{Al}_{2} \mathrm{O}_{3}$ crucible was analyzed. Figure 5(a) shows that an exothermic peak from 613 ${ }^{\circ} \mathrm{C}$ to $800{ }^{\circ} \mathrm{C}$ existed, which is characterized by the interfacial reaction between pure titanium and the $\mathrm{Al}_{2} \mathrm{O}_{3}$ crucible. Further DTA in Figure 5(b), for the mixture of titanium powder 


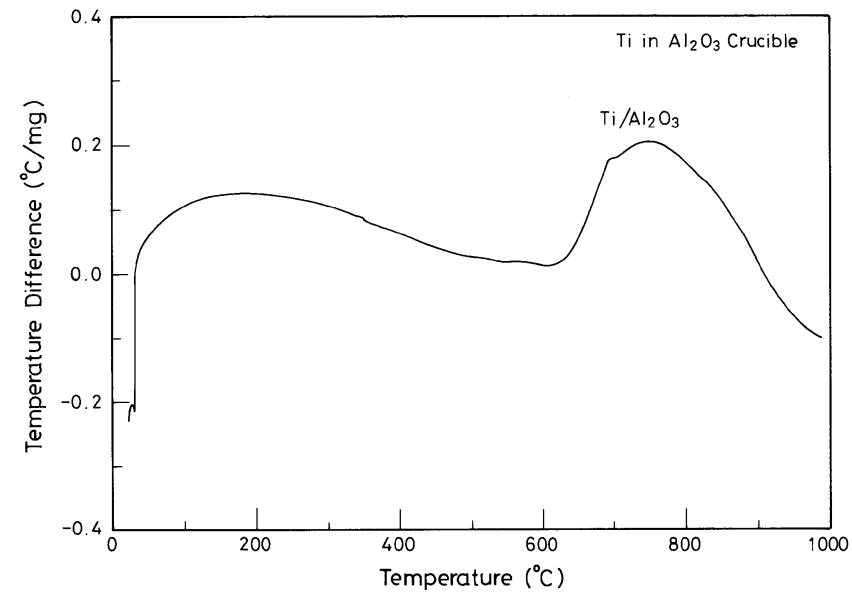

(a)

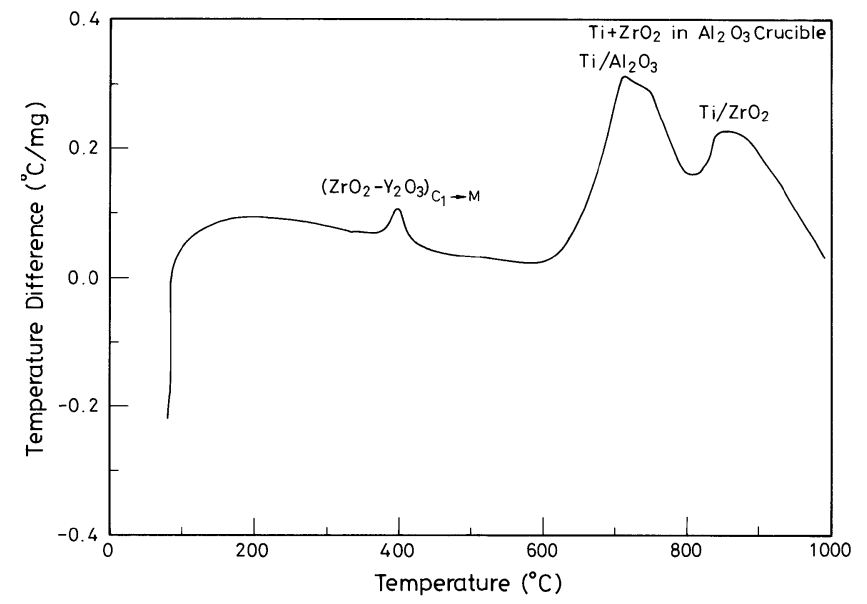

(b)

Fig. 5-DTA analyses for (a) Ti powder and (b) $\mathrm{Ti}+\mathrm{ZrO}_{2}$ powder with $\mathrm{Al}_{2} \mathrm{O}_{3}$ crucible.

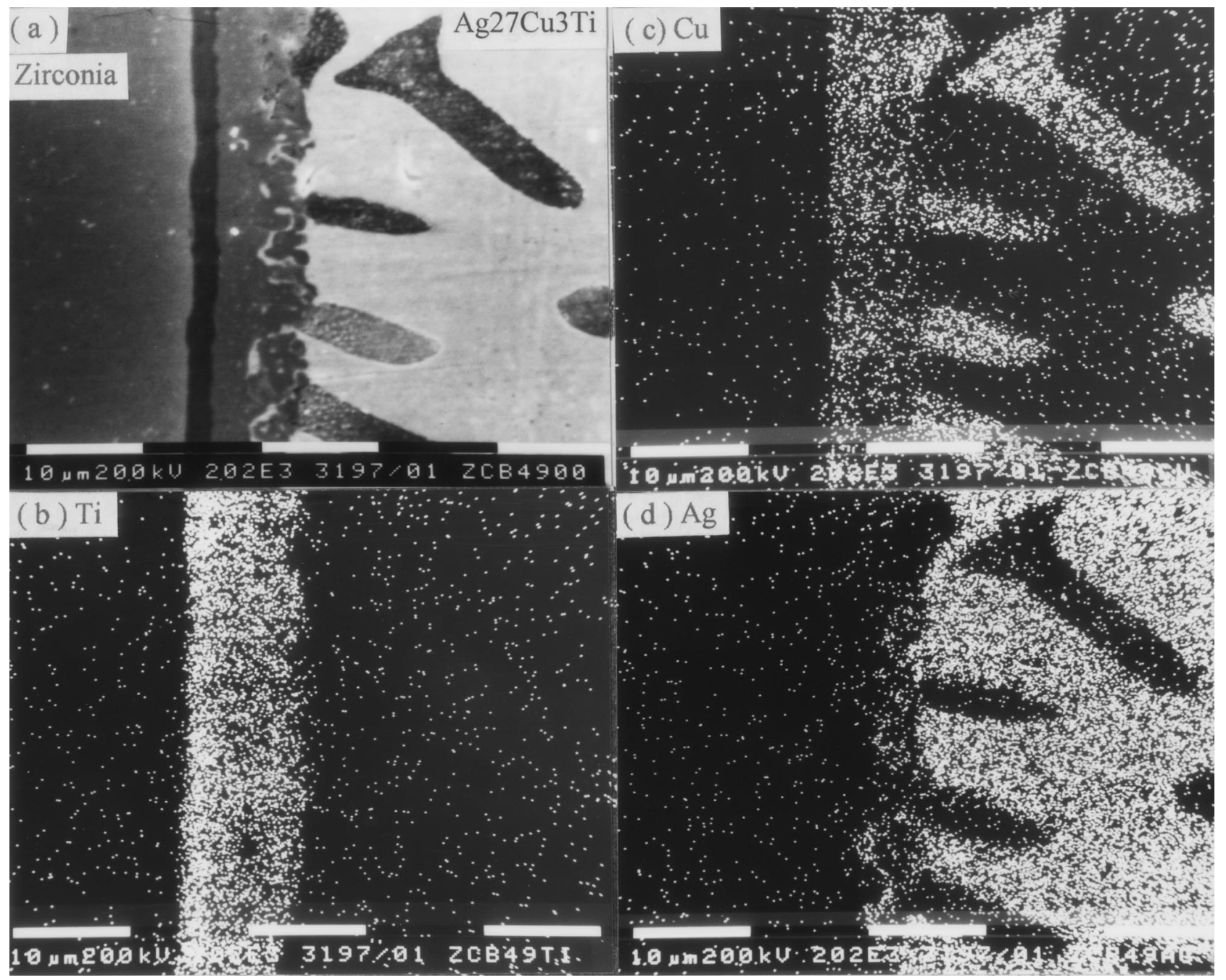

Fig. 6-Micrograph and EPMA analyses for $\mathrm{ZrO}_{2} / \mathrm{Ag} 27 \mathrm{Cu} 3 \mathrm{Ti} / \mathrm{ZrO}{ }_{2}$ system brazed at $900{ }^{\circ} \mathrm{C}$ for $10 \mathrm{~min}:(a)$ interfacial microstructure, $(b)$ titanium mapping, (c) copper mapping, and $(d)$ silver mapping.

and $\mathrm{ZrO}_{2}$ powder contained in the $\mathrm{Al}_{2} \mathrm{O}_{3}$ crucible, showed an exothermic peak from $608{ }^{\circ} \mathrm{C}$ to $804{ }^{\circ} \mathrm{C}$, which represented the interfacial reaction between pure titanium and the
$\mathrm{Al}_{2} \mathrm{O}_{3}$ crucible, as found in Figure 5(a). Since the $\mathrm{ZrO}_{2}$ powder used in the present study was partially stabilized with $5.02 \mathrm{wt}$ pct $\mathrm{Y}_{2} \mathrm{O}_{3}$, it possessed a polymorphic phase 


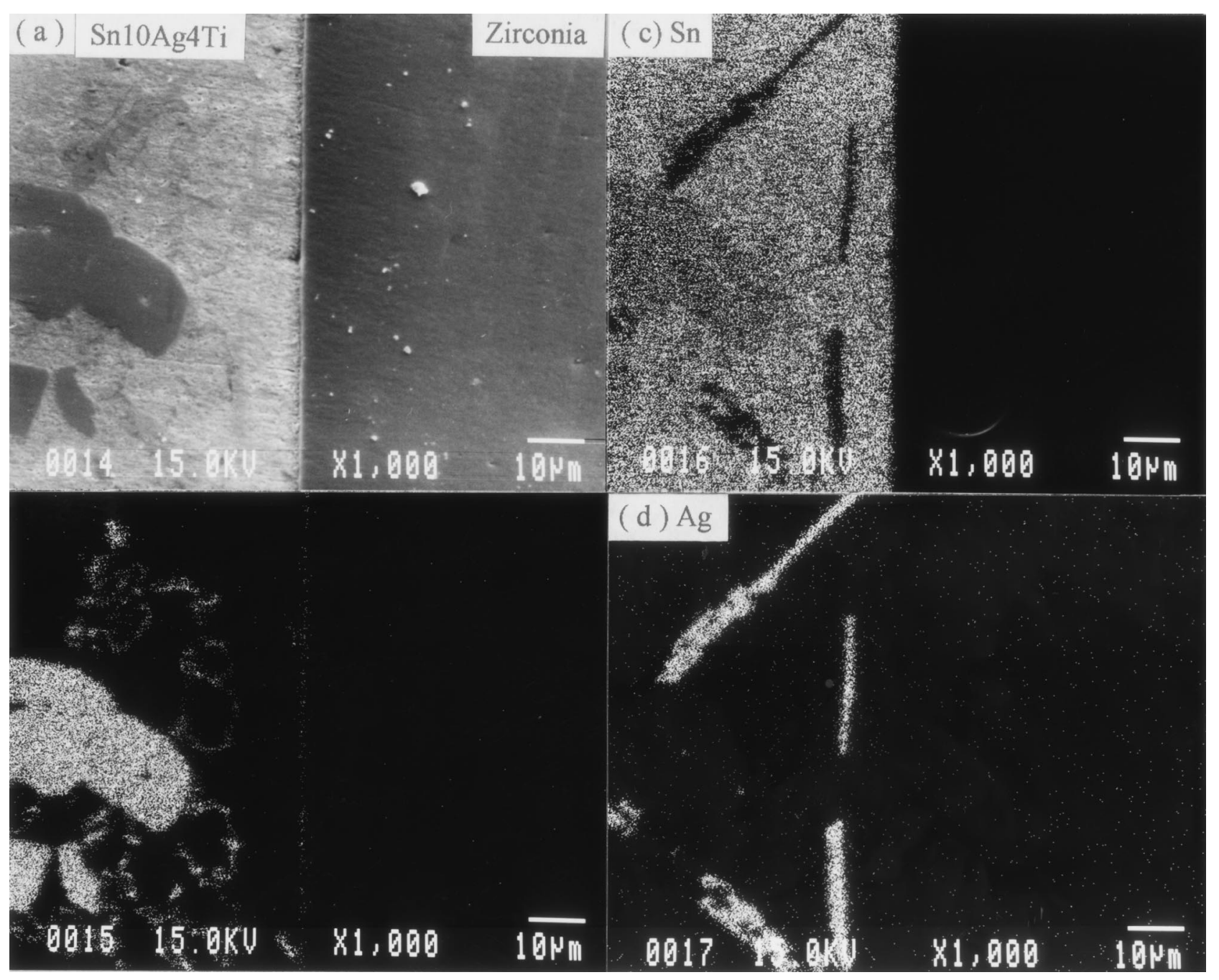

Fig. 7-Micrograph and EPMA analyses for $\mathrm{ZrO}_{2} / \mathrm{Sn} 10 \mathrm{Ag} 4 \mathrm{Ti} / \mathrm{ZrO}_{2}$ system brazed at $700{ }^{\circ} \mathrm{C}$ for $10 \mathrm{~min}:(a)$ interfacial microstructure, $(b)$ titanium mapping, $(c)$ tin mapping, and $(d)$ silver mapping.

transition from a cubic structure (CaF2 type) to a monoclinic structure $(\mathrm{C} 1 \rightarrow \mathrm{M})$ at about $400{ }^{\circ} \mathrm{C}$, according to the report of Srivastava et al. ${ }^{[18]}$ The exothermic peak at approximately $371{ }^{\circ} \mathrm{C}$ to $410{ }^{\circ} \mathrm{C}$ should be attributed to such a $\mathrm{C} 1 \rightarrow \mathrm{M}$ phase transition in $\mathrm{ZrO}_{2}-\mathrm{Y}_{2} \mathrm{O}_{3}$ ceramic powders. The interfacial reaction between pure titanium and $\mathrm{ZrO}_{2}$ could, thus, be evidenced by the other exothermic peak appearing at about $804{ }^{\circ} \mathrm{C}$ to $900{ }^{\circ} \mathrm{C}$.

In referring to the results shown in Figures 4 and 5, the DTA peaks in Figures 3(a) and (b) for $\mathrm{Ag} 27 \mathrm{Cu} 3 \mathrm{Ti} / \mathrm{ZrO}_{2}$ and $\mathrm{Sn} 10 \mathrm{Ag} 4 \mathrm{Ti} / \mathrm{ZrO}{ }_{2}$ can be identified. In Figure 3(a), two endothermic peaks appeared at $775{ }^{\circ} \mathrm{C}$ to $790{ }^{\circ} \mathrm{C}$ and at $930{ }^{\circ} \mathrm{C}$ to $963{ }^{\circ} \mathrm{C}$, representing the melting range of the $\mathrm{Ag} 27 \mathrm{Cu} 3 \mathrm{Ti}$ filler metal and the complete dissolution of the $\mathrm{Cu}$-rich cluster, respectively. The exothermic peak at 790 ${ }^{\circ} \mathrm{C}$ to $810{ }^{\circ} \mathrm{C}$ was attributed to the interfacial reaction of the titanium element in the $\mathrm{Ag} 27 \mathrm{Cu} 3 \mathrm{Ti}$ filler metal with the $\mathrm{Al}_{2} \mathrm{O}_{3}$ crucible. The second exothermic peak at about 310 ${ }^{\circ} \mathrm{C}$ to $400{ }^{\circ} \mathrm{C}$ represented the $(\mathrm{C} 1 \rightarrow \mathrm{M})$ polymorphic phase transition in the $\mathrm{ZrO}_{2}-\mathrm{Y}_{2} \mathrm{O}_{3}$ ceramic. Additionally, the exothermic peak for the interfacial reaction of the titanium element in $\mathrm{Ag} 27 \mathrm{Cu} 3 \mathrm{Ti}$ filler metal with $\mathrm{ZrO}_{2}$ powder appeared at about $870{ }^{\circ} \mathrm{C}$ to $895{ }^{\circ} \mathrm{C}$.

Similarly, in Figure 3(b), the endothermic peak at $219^{\circ} \mathrm{C}$ to $250{ }^{\circ} \mathrm{C}$ correspond to the melting range of Sn10Ag4Ti $\left(221{ }^{\circ} \mathrm{C}\right.$ to $\left.300{ }^{\circ} \mathrm{C}\right)$, as given in Table I. The exothermic peak at about $627{ }^{\circ} \mathrm{C}$ to $750{ }^{\circ} \mathrm{C}$ represented the interfacial reaction of $\mathrm{Ti}(\mathrm{Sn} 10 \mathrm{Ag} 4 \mathrm{Ti})$ with the $\mathrm{Al}_{2} \mathrm{O}_{3}$ crucible. The second exothermic peak at approximately $366{ }^{\circ} \mathrm{C}$ to $455^{\circ} \mathrm{C}$ was attributed to the polymorphic $(\mathrm{C} 1 \rightarrow \mathrm{M})$ transformation. The interfacial reaction of the titanium element in the Sn10Ag4Ti filler metal with $\mathrm{ZrO}_{2}$ powder occurred at the third exothermic peak, at about $860{ }^{\circ} \mathrm{C}$ to $910{ }^{\circ} \mathrm{C}$.

The interfacial microstructure and elemental distributions of the $\mathrm{ZrO}_{2} / \mathrm{Ag} 27 \mathrm{Cu} 3 \mathrm{Ti} / \mathrm{ZrO}_{2}$ joint, after brazing at $900{ }^{\circ} \mathrm{C}$ for 10 minutes, are shown in Figure 6. It is obvious that double reaction layers, with a total thickness of about 12 $\mu \mathrm{m}$, are formed at the interface. The elemental mapping showed that almost all titanium atoms segregated to the double reaction layers. However, the outer layer (near the $\mathrm{ZrO}_{2}$ side), with a thickness of about $2 \mu \mathrm{m}$, possessed more titanium than the inner layer (near the filler-metal side). On the other hand, some copper atoms and silver atoms also segregated to the inner layer, but were absent from the outer layer (Figure 6(c)). Quantitative analyses by EPMA showed that the inner layer consisted of a $\mathrm{Ti}_{2} \mathrm{Cu}$ compound with a small amount of TiAg strips. Since oxygen was mainly found in the outer layer, it can be deduced that the outer layer was 


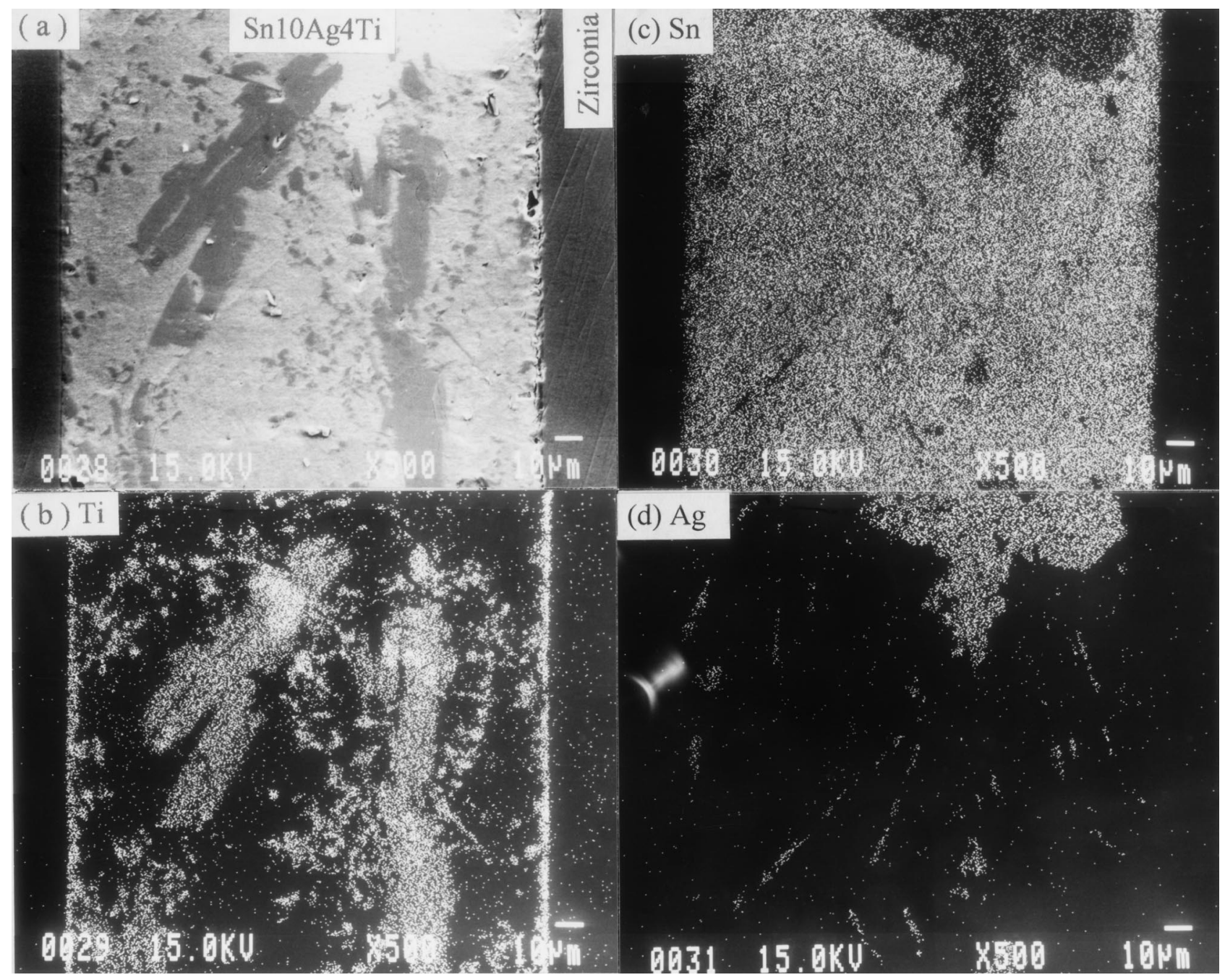

Fig. 8-Micrograph and EPMA analyses for $\mathrm{ZrO}_{2} / \mathrm{Sn} 10 \mathrm{Ag} 4 \mathrm{Ti} / \mathrm{ZrO}_{2}$ system brazed at $900{ }^{\circ} \mathrm{C}$ for $10 \mathrm{~min}$ : (a) interfacial microstructure, $(b)$ titanium mapping, (c) tin mapping, and $(d)$ silver mapping.

composed of TiO. We suggest that the formation of such a $\mathrm{TiO}$ outer layer inhibited the further diffusion of titanium into $\mathrm{ZrO}_{2}$ and caused the reaction of titanium with copper to form a $\mathrm{Ti}_{2} \mathrm{Cu}$ inner layer. This conclusion is consistent with the DTA result in Figure 3(a), which showed an exothermic peak for the interfacial reaction of $\mathrm{Ti}(\mathrm{Ag} 27 \mathrm{Cu} 3 \mathrm{Ti}) / \mathrm{ZrO}_{2}$ at about $870{ }^{\circ} \mathrm{C}$ to $895^{\circ} \mathrm{C}$. A four-point bending test showed that the bonding strength was $227 \mathrm{MPa}$ for $\mathrm{ZrO}_{2} / \mathrm{Ag} 27 \mathrm{Cu} 3 \mathrm{Ti} /$ $\mathrm{ZrO}_{2}$ brazed at $900{ }^{\circ} \mathrm{C}$ for 10 minutes.

Figure 7 shows the micrograph and EPMA elemental mapping for the $\mathrm{ZrO}_{2} / \mathrm{Sn} 10 \mathrm{Ag} 4 \mathrm{Ti} / \mathrm{ZrO}_{2}$ system brazed at 700 ${ }^{\circ} \mathrm{C}$ for 10 minutes. It was found that the titanium clustered in the interior of the Sn10Ag4Ti filler metal after brazing (Figure $7(\mathrm{~b}))$ and reacted with tin to form the (Ti,Sn) compounds (Figure 7(c)), rather than segregating at the filler-metal/ ceramic interface. In addition, some Ag strips with Sn depletion were also observed in the interior of the Sn10Ag4Ti filler metal, attributed to the low solubility of silver in tin (Figure 7(d)). In this case, the bonding strength was very minimal. On increasing the brazing temperature to $900{ }^{\circ} \mathrm{C}$, Ti-rich clusters and $\mathrm{Ag}$ strips in the interior of the $\mathrm{Sn} 10 \mathrm{Ag} 4 \mathrm{Ti}$ filler metal dissolved, and the accumulation of titanium at the $\mathrm{Sn} 10 \mathrm{Ag} 4 \mathrm{Ti} / \mathrm{ZrO}_{2}$ interface was obvious, as shown in
Figure 8 . The bonding strength increased to $137 \mathrm{MPa}$. The attainment of a sound joint for $\mathrm{ZrO}_{2} / \mathrm{Sn} 10 \mathrm{Ag} 4 \mathrm{Ti} / \mathrm{ZrO}_{2}$ with the increase of the brazing temperature to $900^{\circ} \mathrm{C}$ was consistent with the satisfactory wettability of $\mathrm{Sn} 10 \mathrm{Ag} 4 \mathrm{Ti}$ on a $\mathrm{ZrO}_{2}$ substrate at about $900{ }^{\circ} \mathrm{C}$, and both results were correlated to the segregation and reaction of titanium at the Sn10Ag4Ti/ $\mathrm{ZrO}_{2}$ interface. Comparing Figure 8(b) to Figure 6(b), it is interesting to note that the thickness of such a $\mathrm{TiO}$ reaction layer at $\mathrm{ZrO}_{2} / \mathrm{Sn} 10 \mathrm{Ag} 4 \mathrm{Ti}$ was similar to that of the $\mathrm{TiO}$ outer layer at $\mathrm{ZrO}_{2} / \mathrm{Ag} 27 \mathrm{Cu} 3 \mathrm{Ti}$ interface. This observation implies that the nature and formation kinetics of both $\mathrm{TiO}$ interfacial reaction layers were the same, regardless of whether the source of titanium was from $\mathrm{Ag} 27 \mathrm{Cu} 3 \mathrm{Ti}$ or Sn10Ag4Ti.

\section{CONCLUSIONS}

The contact angles of $\mathrm{Ag} 27 \mathrm{Cu} 3 \mathrm{Ti}$ and $\mathrm{Sn} 10 \mathrm{Ag} 4 \mathrm{Ti}$ on zirconia decreased with the increase of brazing temperature and remained at approximately $34 \mathrm{deg}$ and $44 \mathrm{deg}$ above $900{ }^{\circ} \mathrm{C}$, respectively. For the brazing of zirconia with zirconia using Ag27Cu3Ti and Sn10Ag4Ti active filler metals at 900 ${ }^{\circ} \mathrm{C}$ for ten minutes, the respective bonding strengths were 227 and $137 \mathrm{MPa}$. 
During the brazing process, titanium in both filler metals segregated at the ceramic/filler metal interface. The TiO reaction layers in both brazing systems possessed similar thicknesses of about $2 \mu \mathrm{m}$, which implies that the nature and formation kinetics of both $\mathrm{TiO}$ interfacial reaction layers were the same regardless of whether the source of titanium was from $\mathrm{Ag} 27 \mathrm{Cu} 3 \mathrm{Ti}$ or $\mathrm{Sn} 10 \mathrm{Ag} 4 \mathrm{Ti}$.

It was also noted that an exothermic peak appeared at about $870{ }^{\circ} \mathrm{C}$ to $895{ }^{\circ} \mathrm{C}$ in the DTA of $\mathrm{Ag} 27 \mathrm{Cu} 3 \mathrm{Ti}$ mixed with $\mathrm{ZrO}_{2}$ powder, representing the interfacial reaction of $\mathrm{Ti}(\mathrm{Ag} 27 \mathrm{Cu} 3 \mathrm{Ti}) / \mathrm{ZrO}_{2}$. Similarly, an exothermic peak appearing at $810{ }^{\circ} \mathrm{C}$ to $910{ }^{\circ} \mathrm{C}$ was observed in the DTA curve of Sn10Ag4Ti mixed with $\mathrm{ZrO}_{2}$ powder, which was attributed to the interfacial reaction of $\mathrm{Ti}(\mathrm{Sn} 10 \mathrm{Ag} 4 \mathrm{Ti}) / \mathrm{ZrO}_{2}$.

\section{REFERENCES}

1. O.M. Akselsen: J. Mater. Sci., 1992, vol. 27, pp. 1989-2000.

2. M.G. Nicholas: Proc. 3rd Int. Conf. Joining Ceramics, Glass and Metal, W. Kraft, ed., Bad Nauheim, Germany, W. Kraft, ed., Deutsche Gesellschaft Metallkunde e.V., Oberursel, 1989, pp. 3-16.

3. H. Mizuhara and E. Huebel: Weld. J., 1986, vol. 65 (10), pp. 43-45.

4. T. Yano, H. Suematsu, and T. Iseki: J. Mater. Sci., 1988, vol. 23, pp. 3362-66.

5. J.K. Boadi, T. Yano, and T. Iseki: J. Mater. Sci., 1987, vol. 22, pp.
2431-34.

6. R. Xu and J.E. Indacochea: J. Mater. Eng. Perf., 1994, vol. 3 (5), pp. 596-605.

7. M.G. Nicholas and L.M. Jones: Schweissen Schneiden (Welding Cutting, Germany), 1992, vol. 44 (7), pp. 376-79.

8. R.R. Kapoor and T.W. Eagar: J. Am. Ceram. Soc., 1989, vol. 72 (3), pp. $448-54$.

9. E. Lugscheider, W. Tillmann, and W. Weise: Proc. 4th Int. Conf. Joining Ceramics, Glass and Metal, Koenigswinter, Germany, 1993, H. Krappitz and H.A. Schaeffer, eds., Deutsche Glastechnische Gesellschaft e.V., Frankfurt M., 1993, pp. 97-107.

10. L. Dorn and N. Munasinghe: Proc. 5th Int. Conf. Joining Ceramics, Glass and Metal, Jena, Germany, M. Turwitt, ed., DVS-Berichte Band 184, Deutscher Verlag Schweisstechnik, Düsseldorf, 1997, pp. 34-36.

11. T. Okamoto: Iron Steel Inst. Jpn. Int., 1990, vol. 30, pp. 1033-40.

12. Y.S. Chung and T. Iseki: Eng. Fract. Mech., 1991, vol. 40 (4-5), pp. 941-49.

13. A.J. Moorhead and H. Keating: Weld. J., 1986, vol. 65 (10), pp. 17-31.

14. C. Peytour, F. Barbier, and A. Revcolevschi: J. Mater. Res., 1990, vol. 5 (1), pp. 127-35.

15. H. Hao, Z. Jin, and X. Wang: J. Mater. Sci., 1994, vol. 29, pp. 5041-46.

16. P. Martineau, R. Pailler, M. Lahaye, and R. Naslain: J. Mater. Sci., 1984, vol. 19, pp. 2749-70.

17. E. Lugscheider and W. Tillmann: Mater. Manuf. Processes, 1993, vol. 8 (2), pp. 219-38.

18. K.K. Srivastava, R.N. Patil, C.B. Choudhary, K.V.G.K. Gokhale, and E.C. Subbarao: Trans. J. Br. Ceram. Soc., 1974, vol. 73 (3), p. 85; cited from Phase Diagrams for Ceramists, G. Smith, T. Negas, and L.P. Cook, eds., The American Ceramic Society, Westerville, OH, 1981, vol. IV, pp. 141-42. 